IRA-International Journal of Management \& Social Sciences

ISSN 2455-2267; Vol.06, Issue 03 (2017)

Pg. no. 332-344

Institute of Research Advances

https://research-advances.org/index.php/RAJMSS

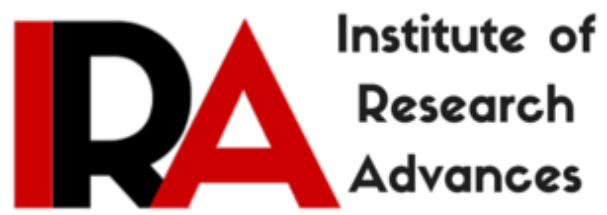

\title{
Institutional Investments and Their Influence on Stock Returns - An Empirical Study
}

\author{
${ }^{1}$ Dr. R. Venkataraman, ${ }^{2}$ Prof. Srinidhi .V.R, ${ }^{3}$ Prof. A.S. Chandramouli \\ ${ }^{1}$ Research Supervisor and Works at Department of Management, Presidency College,Bengaluru, \\ India. \\ ${ }^{2}$ Research Scholar Bharathiar University and Works at Department of Management, \\ Jain University- CMS, Bengaluru, India. \\ ${ }^{3}$ Independent Researcher, Professor in Journalism \& Mass Communication, Bengaluru, India.
}

Type of Review: Peer Reviewed.

DOI: http://dx.doi.org/10.21013/jmss.v6.n3.p1

\section{How to cite this paper:}

Venkataraman, R., V.R, S., \& Chandramouli, A. (2017). Institutional Investments and Their Influence on Stock Returns - An Empirical Study. IRA-International Journal of Management \& Social Sciences (ISSN 2455-2267), 6(3), 332-344. doi:http://dx.doi.org/10.21013/jmss.v6.n3.p1

(C) Institute of Research Advances

(c)) EY-NC

This work is licensed under a Creative Commons Attribution-Non Commercial 4.0 International License subject to proper citation to the publication source of the work.

Disclaimer: The scholarly papers as reviewed and published by the Institute of Research Advances (IRA) are the views and opinions of their respective authors and are not the views or opinions of the IRA. The IRA disclaims of any harm or loss caused due to the published content to any party. 


ABSTRACT
Mutual dependency of market variables is crucial for development of any economy. It is equally
important to study the stock market for what parameter influences over the others and for what length
of time, thus giving direction to investors. Further, Sensex being an important barometer of India's
economic measurement, it would be interesting to know the revelation of its stability while
institutional investors influence it in multiple ways over considerable longer period of economy. This
study investigates the influence of FII and MF on Sensex over 11 year period between 2004-2015. The
objectives were to find out the dependency among the three to conclude about which out theses
influences market the most. On applying Unit-root test, Correlation and VAR, the study revealed that
there was a regime change for BSE-Sensex returns due to the global recession. The noticeable fact is
that change in regime affected the purchase of Mutual Fund which led to increasing in FII investment.
The variation in the investment patterns by institutions brought in heavy market movement. Indian
stock market during the selected period was driven by a greater amount of Foreign Investors
compared to the domestic investors, the Mutual Fund taken up for this study.

Keywords: institutional investors, investment dependency, market movement, market stability, Regime change.

\section{JEL classification: G1, G11, G17, G23}

\section{INTRODUCTION}

India since globalisation has amplified the movement of funds globally as well as internally by introducing innovative financial products and occupying the $21^{\text {st }}$ place in most of Emerging Market Economies $^{1}$ (EMEs), which help a modern investor to get maximum returns through various challenges. One such challenge faced by domestic investors (eg. Mutual Fund- MF) is when they source funds locally and invest them in equities to increase the returns. On the other hand, foreign investors (FII) raise the fund across the globe and try to increase their Return on Investment. In this case the institutional investors play an iconic role in flaring the market of developing countries. The trade of Foreign Institutional Investors (FII) intensify not only the unpredictability in the investors' returns but also the movement of index while the investments of mutual funds have also regularly thrown surprises in the stock market.

This study considers the movement of MF and FII in relation to Indian stock market taking market movements into consideration over FII, MF and the Sensex returns. The purpose of this study is to know how Indian stock market index, in this case, the BSE Sensex responds to MF and FII investments.

\subsection{The Pertinent Research Questions}

This study has the objective to answer the following questions:-

- Which variable emerges out to be dependent or self-reliant among the three chosen measurements?

- What type of investment has what kind of relation with the selected measurement?

\section{REVIEW OF LITERATURE}

Domestic studies in the past have revealed that there has been a positive relation among FII \& MF. Many other studies have found that FII investments depended upon the Indian market performance. Some more domestic studies have also concluded that investment of MFs does notaffect the investment pattern of FII in India.

\footnotetext{
${ }^{1}$ India- incredible investment destination, fact book, Dept. of Economic Affairs, Government of India p15
} 
The present study undertaken by the scholars found wide variation and gaps among the findings and results contravening the above conclusion and inferences. Thus the following review of literature is recorded under this study with fact finding objectives.

Bodla \& Kumar (2009) applied Granger Causality test and found that the net investment made by the foreign institutional investors in Indian stock market was proved as a casual force of market capitalization in the case of trading volume. The increased FII's investment led to increasing in trading volume.

A study (Bulsara, Dhingra, \& Gandhi, 2015) on the flow of Foreign Institutional Investments and stock market returns found that FII increased remarkably from the 1990sonwards which led to increasing in forex reserve and higher value in Indian capital market. Here, the investment made by FII increased volatility. On applying Cross-Correlation Function (CCF) approach, Granger Causality Test and Vector Auto Regression after taking a Global financial crisis, the result observed that there was an interaction between FIIs and Nifty returns.

Dandapani \& Lawrence (2013) established that Indian stock market returns to net FI investments in India had both significant and incremental effect on the returns of Indian stocks. Further, the highinterest rate in India, strong dollar and high US inflation directed a decrease in the investments of FII.

Garg \& Mitra (2015) attempted to evaluate the investment pattern of FIIs' investments and the relation with Indian stock market returns. They concluded that FIIs created short-term volatility. FIIs' bought more than selling and was vulnerable in case of price efficiency.

When investment technology of foreign versus domestic investors is compared (Patnaik \& Shah, 2013) with a focus on decomposing outcomes attributable to asset allocation and security selection, it displayed significant differences in exposure to systematic asset pricing factors between foreign and domestic investors. The results showed that foreign investors in India fare poorly at security selection, while domestic investors farewell.

An analysis (Ray, 2009) on the relationship between foreign institutional investment and stock returns in India (BSE) shows that equity returns caused FII flows into Indian markets but FII flows did not cause equity returns in the Indian stock market. FII investments may be inclined by the previous few days of trading returns and are also influenced by the next trading day's expected returns of the stock market.

On an investigation (Thiripal raju \& Acharya, 2013) about the interaction between institutional investment and market return in Indian stock market, the empirical result showed that FIIs investment is positively related to the lagged market return whereas MFs investment is negatively related to it. Impulse response analysis confirms that impact of shock to market return is more lasting on institutional investment than the other way round. A sub-period analysis confirmed that relationship between FIIs flows and market return did not change significantly during the study period in comparison with MFs.

Tripathi \& Maggo (2015) applied impulse response analysis to estimate the short, as well as the long run relationship among the FII,flows in two markets. There waspositive and high correlation between FII flows in theequity market and in debt market of India. The analysis revealed that FII flows to debt market are significantly responsive to a shock in FII flows to equity market and vice-versa.

(Jangra, 2013) concluded that FII trading activity dampens the market volatility and DII exacerbates market volatility and found that the positive shocks in the trading will have more impact than the negative shocks. In thecase of DII trading, it has led to adisproportionate response in the stock market.

Paramita Mukherjee, (2002) found that FII purchase and sales were dependent on the performance of India's equity market and they established that FII flows were highly auto-correlated. FII flows caused returns of domestic investors. 
Sehgal and Tripathi (2009) used herding method proposed by Lakonishok, Shleifer and Vishny evaluated that FIIs exhibit return-chasing behaviour when monthly data sets were used whereas daily investments of FII did not react to the market information instantly.

A study (Singh, 2014) explored that FIIs played a very important role in Indian stock market and FII injected liquidity and growth in stock markets but at the same time they also inoculated volatility in the stock market. Further concluded that investment of Mutual funds did not affect the investment pattern of FII in India, but the movement of Sensex affected the investment of FIIs.

Sumanjeet and Paliwal (2010) observed that policy of the government, tax code and economic condition significantly affected the movement of the stock index.

Sundaram, (2009) conducted Granger Cointegration and Granger Causality testand found thatthere was no long-runrelationship among foreign exchange and FII. In thecase of Granger Causality, its was found to have unidirectional causality between them.

\section{SOURCES OF DATA}

The secondary data for the purpose of this scientific study were collected from the official websites of BSE, SEBI and NSDL and the variables were synchronised as suitable for the study.

\subsection{Basic Data:}

This study examines the effect of the institutional investment on BSE-Sensex. In this regard, Stock returns were measured using the daily closing prices of the stock index.

\subsection{To calculate stock index returns:}

Daily Rate of Return $=\quad\left(P_{t} / P_{t-1}\right) * 100$

Where $\ln \mathrm{P} t$ is the closing Index of the day, and

Pt-1is the closing Index of previous day

\subsection{Mutual Fund (MF) and Foreign Institutional Investors (FII):}

In the case of MF and FII, daily Gross Purchases \& Gross Sales were considered for the study. MF \& FII values were gathered from SEBI. The Investments are expressed in Crores`.

The investment values are expressed by the natural log of Mutual Fund Gross Purchases, natural log of Gross Sales (MFGP_LN \& MFGS_LN) and natural log value of Foreign Institutional Investments (FIIGP_LN \&FIIGS_LN).Data sets are synchronised\& ensured that the trading days of both time-series are matched. A period of 11 years starting from January 2004 to Dec 2015 was taken for the study. There is atotal of 2,969 observations representing all the trading days gathered and analysed using MS-excel \&Review statistical package.

\section{RESEARCH OBJECTIVE AND METHODOLOGY:}

\subsection{Research objective}

i. To determine the relationship between FII and MF investments and the Sensex returns.

\subsection{Methodology}

ii. To find whether FII or MF investments drive the Indian stock market.

This study examines the effective power of three variables such as Sensex return values, logged investments of FII and logged investments of Mutual Fund. At the point of beginning of this study, BSE Sensex index was chosen to be a dependent variable and the logged investments of FII, as well as the logged investments of Mutual Fund, were taken as predictor variables. 


\subsection{Stationary Test \&Unit root}

Stationary of a series is a stochastic process and plays a vital role in time series, as it influences ordinary least square and generates spurious regression. It is a process of checking mean\& variance over a period of time and if mean and variance of a series are constant over a period of time then the variables become stationary and hence ready for further statistical test and model building.

The Unit Root presence is tested through the Phillips-Perron test

$$
\mathrm{y}_{\mathrm{t}}=\alpha+\rho y_{t-1}+\varepsilon_{t}
$$

The hypothesis for this test is

$\mathrm{H}_{0}: \rho=1$ i.e. time series is non-stationary

$\mathrm{H}_{1}: \rho<1$ i.e. time series is stationary

\subsection{Vector Auto Regression}

VAR model is composed of a system of regressions in which the dependent variables are expressed as a function of their own and each other's lagged values and possibly some other control variables (Enders, 2004). This methodology has proven especially useful for forecasting systems of interrelated time-series variables when the exact theoretical nature of the relationship is dull-witted. The attractive feature of VAR analysis that allows each variable in the system to be treated symmetrically is applicable under this study too. A general unrestricted $\mathrm{pa}^{\text {th }}$-order Gaussian VAR (p) model can be represented as:

$$
y_{\mathrm{it}}=\mathbf{c}+\mathbf{a}_{1} \mathbf{y}_{\mathrm{it}-1}+\mathbf{a}_{2} \mathbf{y}_{\mathrm{it}-2}+\ldots \ldots \ldots+\mathbf{a}_{\mathrm{k}} \mathbf{y}_{\mathrm{it}-\mathrm{p}}+\varepsilon_{\mathrm{t}}
$$

Where, $\mathrm{y}_{i t}$ is a vector of variables, $\mathrm{c}$ is a $p X 1$ vector of intercepts, $a_{1} a_{2} a_{3} \& a_{k}$ are $p X p$ matrices of parameters, $\varepsilon_{t}$ is a vector of uncorrelated structural shocks.

\subsection{Lag Length VAR (p)}

As a successful model depends on a right number of lags, too many lags included make the model less effective and the estimators inefficient. Hence the essentiality to define a comprehensive model herein adopted the VAR model. In this study, lag length was considered on the basis of Akaike Information Criterion (AIC).

\subsection{Impulse response function}

Impulse response serves as an important function, which allows to trace the path, time and impact of an innovation in one variable on all other variables included in VAR model. A change in error term will change the future value of other variables. These innovations (i.e. errors) are usually correlated. In this study, innovations were checked for LM correlation test, which is statistically significant and Cholesky decomposition method has been used.

\section{EMPIRICAL RESULTS}

\subsection{Unit root test}

Table-1: UNITROOT TEST

\begin{tabular}{|c|c|c|c|c|c|c|}
\hline \multicolumn{3}{|c|}{$\mathrm{H}_{0}$ : variables has a unit root } & & \multicolumn{3}{|c|}{$\mathrm{H}_{1}$ : variables are stationary } \\
\hline Variable & & t-Statistic & Prob.* & $1 \%$ & $5 \%$ & $10 \%$ \\
\hline SENSEXR $_{\mathrm{t}}$ & $\begin{array}{l}\text { Trend \& } \\
\text { Intercept }\end{array}$ & -50.83480 & 0.0000 & -3.961129 & -3.411318 & -3.127502 \\
\hline MFGP_LN & $\begin{array}{l}\text { Trend \& } \\
\text { Intercept }\end{array}$ & -55.25744 & 0.0000 & -3.961129 & -3.411318 & -3.127502 \\
\hline MFGS_LN & $\begin{array}{l}\text { Trend \& } \\
\text { Intercept }\end{array}$ & -59.80284 & 0.0000 & -3.961129 & -3.411318 & -3.127502 \\
\hline FIIGP_LN & $\begin{array}{l}\text { Trend \& } \\
\text { Intercept }\end{array}$ & -48.02861 & 0.0000 & -3.961129 & -3.411318 & -3.127502 \\
\hline
\end{tabular}

TABLE-1: Phillips-Perron Test 


$\begin{array}{lllllll}\text { FIIGS_LN } & \begin{array}{l}\text { Trend \& } \\ \text { Intercept }\end{array} & -46.24249 & 0.0000 & -3.961129 & -3.411318 & -3.127502 \\ \text { indicates test significance at all levels. }\end{array}$

Table 1 presents the results of Phillips-Perron Test for SENSEXR $\mathrm{t}_{\mathrm{t}}$ along with portfolio investments, i.e. MFGP_LN, MFGS_LN, FIIGP_LNand FIIGS_LN. All the variables were stationary at level.

\subsection{Multiple Breakpoint tests}

6 Table 2: Sequential F-statistic determined breaks

$\begin{array}{cccc} & & \text { Scaled } & \text { Critical } \\ \text { Break Test } & \text { F-statistic } & \text { F-statistic } & \text { Value** } \\ 0 \text { vs. } 1 * & 6.510127 & 32.55064 & 18.23 \\ 1 \text { vs. } 2 & 2.720667 & 13.60334 & 19.91 \\ & \text { Break dates } & \\ \text { Sequential } & \text { Repartition } & \\ \text { 03/08/2009 } & 03 / 08 / 2009 & \\ \text { * Significant at the 0.05 level. } & \\ \text { ** Bai-Perron (Econometric Journal, 2003) critical values. }\end{array}$

The Bai-perron sequential break table shows that there was a sequential break in $\operatorname{SENSEXR}_{t}$ on August $03^{\text {rd }}, 2009$ as per F- Stats. The break is the outcome of the Global Slowdown at the time, which is a visible regime change.

\subsection{Descriptive statistic}

$\begin{array}{lrrll}\text { Mean } & 7 & \text { Table }-3 \text { Descriptive stats } & \\ & \text { Std. Dev. } & \text { Skewness Kurtosis } & \begin{array}{l}\text { Jarque- } \\ \text { Bera }\end{array} & \text { Observations }\end{array}$

$\begin{array}{lllllll}\text { SENSEXR }_{\mathbf{t}} & 0.000914 & 0.018390 & -0.079726 & 5.325170 & 312.3309 & 1380 \\ \text { MFGP_LN } & 2.605616 & 0.345532 & -1.003048 & 6.047166 & 765.3041 & 1380 \\ \text { MFGS_LN } & 2.584366 & 0.335832 & -1.508820 & 10.67863 & 3913.884 & 1380 \\ \text { FIIGP_LN } & 3.201878 & 0.329918 & -0.819835 & 5.738907 & 585.9325 & 1380 \\ \text { FIIGS_LN } & 3.159722 & 0.357242 & -1.026807 & 7.152969 & 1234.208 & 1380\end{array}$

\begin{tabular}{|c|c|c|c|c|c|c|}
\hline \multicolumn{7}{|c|}{ 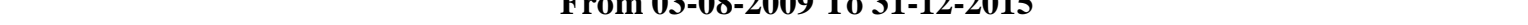 } \\
\hline SENSEXR $_{t}$ & 0.000389 & 0.010592 & -0.111915 & 4.371194 & 127.8002 & 1589 \\
\hline MFGP_LN & 2.764333 & 0.280102 & -3.791414 & 42.96651 & 109563.0 & 1589 \\
\hline MFGS_LN & 2.770656 & 0.265852 & -4.768386 & 42.73935 & 110578.9 & 1589 \\
\hline FIIGP_LN & 3.482812 & 0.193061 & 0.079847 & 5.112998 & 297.2929 & 1589 \\
\hline FIIGS_LN & 3.442020 & 0.198709 & -0.066327 & 5.182518 & 316.5409 & 1589 \\
\hline
\end{tabular}

The table represents average returns, investments and variation of the three variables. Sensex returns have decreased after the break date (03-08-2009), average gross purchases and sales of FII and MF had increased. Skewness and Kurtosis explain about symmetry and shape of the above distribution, the skewness is along tail to the left; the values are negativelyskewed; however natural log of FIIGross Purchases is along tail to the right and are positively skewed. In the case of kurtosis, variables are greater than 3, which demonstrate its response from the impacts of any latest information to the stock market. Jarque-Bera's p-value is far smaller than the significance level, so it doesn't conform to the normal distribution. 


\subsection{Correlation analysis}

Table-4: Correlation

\begin{tabular}{cc}
\multicolumn{1}{c}{ Correlated Pair } \\
& MFGP_LN \\
SENSEXR $_{\mathrm{t}}$ & MFGS_LN \\
& FIIGP_LN \\
& FIIGS_LN
\end{tabular}

Correlated Pair

$\begin{array}{ll} & \text { MFGS_LN } \\ \text { MFGP_LN } & \text { FIIGP_LN } \\ & \text { FIIGS_LN }\end{array}$

Correlated Pair

MFGS_LN
From 02-01-2004 To From 03-08-2009 To 3131-07-2009

12-2015

$-0.0132-0.0028$

$0.0512 \quad 0.0659$

$0.0054 \quad 0.0486$

$-0.07400 \quad-0.0037$

From 02-01-2004 To From 03-08-2009 To 31-

31-07-2009 12-2015

$0.8407 \quad 0.7223$

$0.6352 \quad 0.2834$

$0.6513 \quad 0.3721$

From 02-01-2004 To From 03-08-2009 To 3131-07-2009 12-2015

$0.6586 \quad 0.2687$

$0.6331 \quad 0.2158$

Table-4 explains the relation between the variables. Sensex shares positive low level of relation with MF and FII Gross Sales and Purchases. MF Gross Purchases and Gross Sales have a positive relation with FII Gross Purchases and Sales during 2004-2009 and the relation decreased during 2009-2015. In case MF gross sales relation with FII gross purchases and sales has reduced drastically from high positive correlation to low correlation during 2009 to 2015.

7.3 VAR $(p)$

8 Table-5: VAR Lag Order Selection Criteria

9 From 02-01-2004 to 31-07-2009 Endogenous variables: SENSEXR

10

$\begin{array}{ccccccl}\text { Lag } & \text { LogL } & \text { LR } & \text { FPE } & \text { AIC } & \text { SC } & \text { HQ } \\ 0 & 4300.031 & \text { NA } & 1.31 \mathrm{e}-09 & -6.260978 & -6.241940 & -6.253854 \\ 1 & 5665.370 & 2718.736 & 1.86 \mathrm{e}-10 & -8.214825 & -8.100597 & -8.172081 \\ 2 & 5784.542 & 236.4322 & 1.62 \mathrm{e}-10 & -8.352101 & -8.142684^{*} & -8.273737 \\ 3 & 5868.274 & 165.5125 & 1.49 \mathrm{e}-10 & -8.437718 & -8.133110 & -8.323734 \\ 4 & 5934.786 & 130.9880 & 1.40 \mathrm{e}-10 & -8.498231 & -8.098433 & -8.348627 \\ 5 & 5997.551 & 123.1502 & 1.33 \mathrm{e}-10 & -8.553281 & -8.058293 & -8.368057 * \\ 6 & 6033.784 & 70.82969 & 1.31 \mathrm{e}-10^{*} & -8.569656^{*} & -7.979479 & -8.348813 \\ 7 & 6058.675 & 48.47421 & 1.31 \mathrm{e}-10 & -8.569496 & -7.884129 & -8.313033 \\ 8 & 6078.395 & 38.26221^{*} & 1.32 \mathrm{e}-10 & -8.561800 & -7.781243 & -8.269716\end{array}$

11

$\begin{array}{ccc}\text { Lag } & \text { LogL } & \text { LR } \\ 0 & 7049.406 & \text { NA } \\ 1 & 7966.591 & 1827.407 \\ 2 & 8088.312 & 241.7482 \\ 3 & 8156.935 & 135.8569 \\ 4 & 8224.423 & 133.1841 \\ 5 & 8293.954 & 136.7750\end{array}$

From 03-08-2009 to 31-12-2015

$\begin{array}{cccc}\text { FPE } & \text { AIC } & \text { SC } & \text { HQ } \\ 9.28 \mathrm{e}-11 & -8.911330 & -8.894360 & -8.905025 \\ 3.00 \mathrm{e}-11 & -10.03996 & -9.938145 & -10.00213 \\ 2.66 \mathrm{e}-11 & -10.16232 & -9.975651^{*} & -10.09296 \\ 2.51 \mathrm{e}-11 & -10.21750 & -9.945986 & -10.11662 \\ 2.38 \mathrm{e}-11 & -10.27125 & -9.914887 & -10.13884 \\ 2.25 \mathrm{e}-11 & -10.32758 & -9.886371 & -10.16365^{*}\end{array}$




$\begin{array}{lllllll}6 & 8316.828 & 44.85148 & 2.26 \mathrm{e}-11 & -10.32489 & -9.798833 & -10.12943 \\ 7 & 8329.561 & 24.88478 & 2.29 \mathrm{e}-11 & -10.30937 & -9.698466 & -10.08239 \\ 8 & 8369.500 & 77.80653 * & 2.25 \mathrm{e}-11 * & -10.32827 * & -9.632516 & -10.06976\end{array}$

* indicates lag order selected by the criterion

LR: sequential modified LR test statistic (each test at 5\% level),

FPE: Final prediction error

AIC: Akaike information criterion, SC: Schwarz information criterion \&

HQ: Hannan-Quinn information criterion

VAR Lag Order Selection Criteria is considered by taking AIC value so that a dynamic VAR model can be built.

\subsection{Variance Decomposition}

Table-6: Variance Decomposition

From 02-01-2004 to 31-07-2009

Variance Decomposition of FIIGP_LN:

$\begin{array}{ccccccc}\text { Period } & \text { S.E. } & \text { FIIGP_LN } & \text { MFGP_LN } & \text { MFGS_LN } & \text { FIIGS_LN } & \text { SENSEXR }^{+} \\ 1 & 0.155655 & 100.0000 & 0.000000 & 0.000000 & 0.000000 & 0.000000 \\ 2 & 0.199788 & 63.58865 & 31.13000 & 5.086016 & 0.009957 & 0.185378 \\ 3 & 0.207254 & 60.94498 & 33.05794 & 5.772843 & 0.051857 & 0.172379 \\ 4 & 0.210160 & 60.17024 & 33.53553 & 5.834733 & 0.236680 & 0.222814 \\ 5 & 0.214350 & 59.42212 & 33.45292 & 6.197897 & 0.697225 & 0.229841 \\ 6 & 0.218743 & 58.67638 & 33.98509 & 6.190279 & 0.672768 & 0.475484 \\ 7 & 0.223704 & 57.16111 & 34.87951 & 6.355401 & 0.654997 & 0.948989 \\ 8 & 0.228565 & 56.04782 & 35.64753 & 6.699720 & 0.628189 & 0.976743 \\ 9 & 0.233878 & 54.63808 & 36.82455 & 6.955363 & 0.618185 & 0.963824 \\ 10 & 0.237882 & 53.50054 & 37.64880 & 7.285615 & 0.628299 & 0.936748\end{array}$

Variance Decomposition of MFGP_LN:

$\begin{array}{ccccccc}\text { Period } & \text { S.E. } & \text { FIIGP_LN } & \text { MFGP_LN } & \text { MFGS_LN } & \text { FIIGS_LN } & \text { SENSEXR }_{\mathrm{t}} \\ 1 & 0.219133 & 0.005933 & 99.99407 & 0.000000 & 0.000000 & 0.000000 \\ 2 & 0.227702 & 0.005666 & 99.62204 & 0.000336 & 0.196880 & 0.175077 \\ 3 & 0.231503 & 0.015459 & 99.51691 & 0.066788 & 0.213915 & 0.186926 \\ 4 & 0.233887 & 0.024214 & 99.46640 & 0.099611 & 0.224079 & 0.185698 \\ 5 & 0.237664 & 0.081114 & 99.25774 & 0.244196 & 0.230533 & 0.186413 \\ 6 & 0.243007 & 0.108600 & 98.13688 & 0.648387 & 0.370690 & 0.735448 \\ 7 & 0.247607 & 0.161715 & 98.00213 & 0.702291 & 0.361944 & 0.771916 \\ 8 & 0.253920 & 0.604126 & 97.28745 & 0.766583 & 0.428042 & 0.913802 \\ 9 & 0.258312 & 0.711008 & 96.98650 & 0.936305 & 0.482973 & 0.883215 \\ 10 & 0.261948 & 0.799594 & 96.74129 & 1.099932 & 0.495746 & 0.863439\end{array}$

\begin{tabular}{ccrrrrr}
\multicolumn{7}{c}{ Variance Decomposition of MFGS_LN: } \\
Period & S.E. & FIIGP_LN & MFGP_LN & MFGS_LN & FIIGS_LN & SENSEXR $_{\mathrm{t}}$ \\
1 & 0.217066 & 0.655570 & 44.82695 & 54.51748 & 0.000000 & 0.000000 \\
2 & 0.222698 & 0.841614 & 44.26609 & 54.58943 & 0.302106 & 0.000764 \\
3 & 0.226130 & 0.877978 & 44.93225 & 53.25491 & 0.552433 & 0.382425 \\
4 & 0.229650 & 0.999303 & 44.93625 & 52.62139 & 1.002652 & 0.440406 \\
5 & 0.234224 & 1.197946 & 45.60264 & 51.46444 & 1.181712 & 0.553261 \\
6 & 0.239317 & 1.250518 & 45.78961 & 50.80273 & 1.185341 & 0.971794 \\
7 & 0.244360 & 1.504015 & 46.58024 & 49.74722 & 1.163773 & 1.004756 \\
8 & 0.249604 & 2.134616 & 46.88797 & 48.64667 & 1.118345 & 1.212392 \\
9 & 0.253367 & 2.310678 & 47.52388 & 47.84214 & 1.146600 & 1.176698 \\
10 & 0.256714 & 2.470795 & 48.11025 & 47.10148 & 1.169905 & 1.147576
\end{tabular}

Variance Decomposition of FIIGS_LN:

$\begin{array}{ccccccc}\text { Period } & \text { S.E. } & \text { FIIGP_LN } & \text { MFGP_LN } & \text { MFGS_LN } & \text { FIIGS_LN } & \text { SENSEXR }_{\mathrm{t}} \\ 1 & 0.166141 & 52.79990 & 0.135720 & 0.450252 & 46.61413 & 0.000000 \\ 2 & 0.208516 & 34.82667 & 30.34409 & 2.969580 & 31.66157 & 0.198083\end{array}$




$\begin{array}{ccccccc}3 & 0.215384 & 33.98073 & 31.82705 & 3.933775 & 30.06919 & 0.189253 \\ 4 & 0.217602 & 33.81552 & 32.20498 & 4.023096 & 29.77059 & 0.185812 \\ 5 & 0.220748 & 34.06742 & 32.31309 & 4.399256 & 29.00848 & 0.211747 \\ 6 & 0.226779 & 33.56374 & 33.35908 & 4.776989 & 27.95851 & 0.341683 \\ 7 & 0.232695 & 32.32084 & 35.09273 & 4.824819 & 26.86946 & 0.892150 \\ 8 & 0.237305 & 32.06349 & 35.60226 & 5.124502 & 26.30702 & 0.902728 \\ 9 & 0.242990 & 31.47668 & 36.95433 & 5.495553 & 25.18109 & 0.892340 \\ 10 & 0.247355 & 30.94779 & 37.92319 & 5.925950 & 24.33749 & 0.865584\end{array}$

\begin{tabular}{ccccccc} 
Period & S.E. & FIIGP_LN & MFGP_LN & MFGS_LN & FIIGS_LN & SENSEXR $_{\mathrm{t}}$ \\
1 & 0.017550 & 0.016132 & 0.020799 & 1.594619 & 1.795926 & 96.57252 \\
2 & 0.017829 & 0.042039 & 0.080843 & 1.805872 & 4.447332 & 93.62391 \\
3 & 0.017970 & 0.045315 & 0.199182 & 1.884891 & 5.247420 & 92.62319 \\
4 & 0.018130 & 0.339466 & 0.956740 & 1.975417 & 5.724092 & 91.00429 \\
5 & 0.018236 & 0.610253 & 0.979085 & 2.226970 & 6.186012 & 89.99768 \\
6 & 0.018490 & 0.613629 & 1.179829 & 4.570088 & 6.034942 & 87.60151 \\
7 & 0.018608 & 0.841277 & 1.164891 & 4.644870 & 5.960245 & 87.38872 \\
8 & 0.018616 & 0.841294 & 1.170667 & 4.705871 & 5.960597 & 87.32157 \\
9 & 0.018619 & 0.842965 & 1.187718 & 4.710923 & 5.963536 & 87.29486 \\
10 & 0.018621 & 0.842924 & 1.190966 & 4.726360 & 5.967250 & 87.27250 \\
\multicolumn{7}{c}{ Cholesky Ordering: FIIGP_LN MFGP_LN MFGS_LN FIIGS_LN SENSEXRT }
\end{tabular}

From 03-08-2009 to 31-12-2015

$\begin{array}{cc}\text { Period } & \text { S.E. } \\ 1 & 0.241260 \\ 2 & 0.245927 \\ 3 & 0.248865 \\ 4 & 0.250862 \\ 5 & 0.252737 \\ 6 & 0.254903 \\ 7 & 0.255832 \\ 8 & 0.256946 \\ 9 & 0.258536 \\ 10 & 0.259230\end{array}$

Variance Decomposition of MFGS_LN:

$\begin{array}{ccrrc}\text { MFGS_LN } & \text { MFGP_LN } & \text { FIIGS_LN } & \text { FIIGP_LN } & \text { SENSEXR }_{\mathrm{t}} \\ 100.0000 & 0.000000 & 0.000000 & 0.000000 & 0.000000 \\ 99.60001 & 0.152514 & 0.112206 & 0.072521 & 0.062744 \\ 98.72273 & 0.703089 & 0.170327 & 0.339746 & 0.064108 \\ 98.02127 & 0.759144 & 0.281465 & 0.821722 & 0.116404 \\ 97.13272 & 0.752583 & 0.525712 & 1.427512 & 0.161478 \\ 96.63721 & 0.909740 & 0.535815 & 1.716448 & 0.200789 \\ 96.55262 & 0.906108 & 0.541883 & 1.790506 & 0.208880 \\ 96.07982 & 0.930664 & 0.543309 & 2.236737 & 0.209468 \\ 95.53422 & 1.272960 & 0.618758 & 2.366245 & 0.207821 \\ 95.25678 & 1.389569 & 0.650229 & 2.492317 & 0.211109\end{array}$

Variance Decomposition of MFGP_LN:

$\begin{array}{cccrrrc}\text { Period } & \text { S.E. } & \text { MFGS_LN } & \text { MFGP_LN } & \text { FIIGS_LN } & \text { FIIGP_LN } & \text { SENSEXR }_{\mathrm{t}} \\ 1 & 0.236059 & 55.98116 & 44.01884 & 0.000000 & 0.000000 & 0.000000 \\ 2 & 0.243216 & 56.10206 & 43.07313 & 0.308247 & 0.504741 & 0.011822 \\ 3 & 0.247204 & 55.76784 & 43.05058 & 0.316525 & 0.853611 & 0.011445 \\ 4 & 0.250134 & 55.18588 & 42.83437 & 0.986849 & 0.837429 & 0.155469 \\ 5 & 0.253107 & 54.61605 & 42.21411 & 2.103442 & 0.831120 & 0.235282 \\ 6 & 0.256466 & 54.28836 & 42.26158 & 2.373051 & 0.811771 & 0.265239 \\ 7 & 0.258884 & 54.23108 & 42.37273 & 2.329820 & 0.797313 & 0.269062 \\ 8 & 0.260114 & 53.99365 & 42.56703 & 2.308640 & 0.802791 & 0.327887 \\ 9 & 0.263943 & 53.50631 & 42.36935 & 3.018577 & 0.785118 & 0.320641 \\ 10 & 0.266216 & 53.17927 & 42.25757 & 3.464306 & 0.775079 & 0.323774\end{array}$

\begin{tabular}{ccccccc}
\multicolumn{7}{c}{ Variance Decomposition of FIIGS_LN: } \\
Period & S.E. & MFGS_LN & MFGP_LN & FIIGS_LN & FIIGP_LN & SENSEXR $_{\mathrm{t}}$ \\
1 & 0.142076 & 0.374238 & 0.169158 & 99.45660 & 0.000000 & 0.000000 \\
2 & 0.155018 & 4.038071 & 1.938190 & 93.81851 & 0.138807 & 0.066422 \\
3 & 0.162420 & 5.597257 & 2.914469 & 91.08371 & 0.232535 & 0.172027 \\
4 & 0.165157 & 6.488671 & 2.973211 & 90.04827 & 0.242584 & 0.247268 \\
5 & 0.169934 & 7.374519 & 2.850022 & 89.21079 & 0.238814 & 0.325857 \\
6 & 0.173736 & 7.815047 & 2.940026 & 88.55904 & 0.333396 & 0.352489 \\
7 & 0.176873 & 8.083599 & 3.573889 & 87.48817 & 0.326430 & 0.527915 \\
8 & 0.179339 & 8.164442 & 4.143039 & 86.60225 & 0.493456 & 0.596813
\end{tabular}




$\begin{array}{ccccccc}9 & 0.181569 & 8.005457 & 4.576000 & 85.98762 & 0.721179 & 0.709742 \\ 10 & 0.183672 & 8.087480 & 4.948147 & 85.34740 & 0.893233 & 0.723738\end{array}$

\begin{tabular}{ccccccc}
\multicolumn{7}{c}{ Variance Decomposition of FIIGP_LN: } \\
Period & S.E. & MFGS_LN & MFGP_LN & FIIGS_LN & FIIGP_LN & SENSEXR $_{\mathrm{t}}$ \\
1 & 0.143742 & 0.953303 & 0.389863 & 67.16051 & 31.49633 & 0.000000 \\
2 & 0.155634 & 4.853220 & 1.549027 & 63.40899 & 30.04320 & 0.145563 \\
3 & 0.162116 & 6.514235 & 2.343433 & 61.35270 & 29.51628 & 0.273350 \\
4 & 0.165371 & 7.685487 & 2.311094 & 59.74326 & 29.82371 & 0.436447 \\
5 & 0.169337 & 8.604866 & 2.218564 & 59.78821 & 28.82588 & 0.562486 \\
6 & 0.173733 & 9.228713 & 2.172505 & 59.15616 & 28.77301 & 0.669615 \\
7 & 0.176370 & 9.671318 & 2.420927 & 58.65331 & 28.54721 & 0.707244 \\
8 & 0.178707 & 9.715618 & 2.830842 & 57.99334 & 28.66573 & 0.794465 \\
9 & 0.180930 & 9.497015 & 2.974275 & 57.33087 & 29.28829 & 0.909551 \\
10 & 0.182883 & 9.502711 & 3.135232 & 56.82399 & 29.61312 & 0.924947
\end{tabular}

$\begin{array}{ccccccc}\text { Period } & \text { S.E. } & \text { MFGS_LN } & \text { MFGP_LN } & \text { FIIGS_LN } & \text { FIIGP_LN } & \text { SENSEXR }_{\mathrm{t}} \\ 1 & 0.009727 & 0.145449 & 0.038934 & 0.081728 & 0.000173 & 99.73372 \\ 2 & 0.009760 & 0.182575 & 0.181962 & 0.215290 & 0.017411 & 99.40276 \\ 3 & 0.009788 & 0.280790 & 0.213545 & 0.214325 & 0.017972 & 99.27337 \\ 4 & 0.009843 & 0.384222 & 0.686564 & 0.263699 & 0.063244 & 98.60227 \\ 5 & 0.009940 & 0.480623 & 0.815010 & 0.564962 & 1.432168 & 96.70724 \\ 6 & 0.010359 & 0.456124 & 1.075805 & 0.731174 & 8.665143 & 89.07175 \\ 7 & 0.010522 & 0.502550 & 1.053868 & 0.766954 & 11.34439 & 86.33224 \\ 8 & 0.010622 & 0.524572 & 1.039378 & 1.153798 & 12.56659 & 84.71566 \\ 9 & 0.010680 & 0.522928 & 1.530710 & 1.183478 & 12.78833 & 83.97455 \\ 10 & 0.010683 & 0.548227 & 1.531433 & 1.186029 & 12.79184 & 83.94247 \\ & \text { Cholesky Ordering: MFGS_LN MFGP_LN FIIGS_LN FIIGP_LN SENSEXR } & \end{array}$

The study aims at finding Variance Decomposition of each variable for about 10 days based on Cholesky Scale. As per table-6, during 02-01-2004 and 31-07-2009, FII Gross Purchases was selfreliant to a large extent (54 percent)for purchases however it still depended on Mutual Fund Gross Purchases to a fair extent (38 percent). Whereas Mutual Fund Gross Purchases was almost selfdependent (97 percent) but depended to a feeble extent on other variables ( 3 percent). Nearly a half of Mutual Fund Gross Sales was effected by its own Purchases (48 percent) and almost another half by its own Sales (47 percent). It depended least on FII Purchases (2.47 percent). More than a third of FII Gross Sales are caused by MF Gross Purchases (38 percent); nearly another third of the Sales were caused by FII Gross Purchases (31 percent), self-dependent to a fair extent (27 percent) and least on remaining variables (4 percent). In the case of Sensex Returns are largely affected (87 percent) by its movement; another variable such as FII Gross Sales (6 percent), MF Gross Sales (5 percent), but least dependent on remaining variables ( 2 percent).

Between 03-08-2009 \& 31-12-2015, Variance Decomposition for MF Gross Sales shows that it largely depended on itself (95 Percent) and very little relied on FII Gross Purchase (3 Percent), and very meagrely on other variables (2 Percent).In the case of MF Gross Purchases, more than half of it got effected by MF Gross Sales (53 Percent), it was self-reliant to nearly half of it (42Percent)and got least effected by other variables (5 Percent). On the other hand, FII Gross Sales depended upon itself to a large extent (85 Percent),got effected a bit by MF Gross Sales ( 8 Percent), by MF Gross Purchases upto5\% and by FII Gross Purchases $-1 \%$, also by Sensex Returns upto 1\%. More than half of FII Gross Purchases got effected by FII Gross Sales (57 Percent), it was self-dependent to nearly a third of itself (29 Percent), by MF Gross Sales upto10\%, by MF Gross Purchase - 3\%, Sensex Returns- $1 \%$.In the case of Sensex returns, it was almost self-reliant (84 Percent), a quarter of it got effected by FII Gross Purchase (13 Percent), and by other variables upto 3\%. 


\subsection{Impulse response function}

\section{Figure -1}

From 02-01-2004 to 31-07-2009
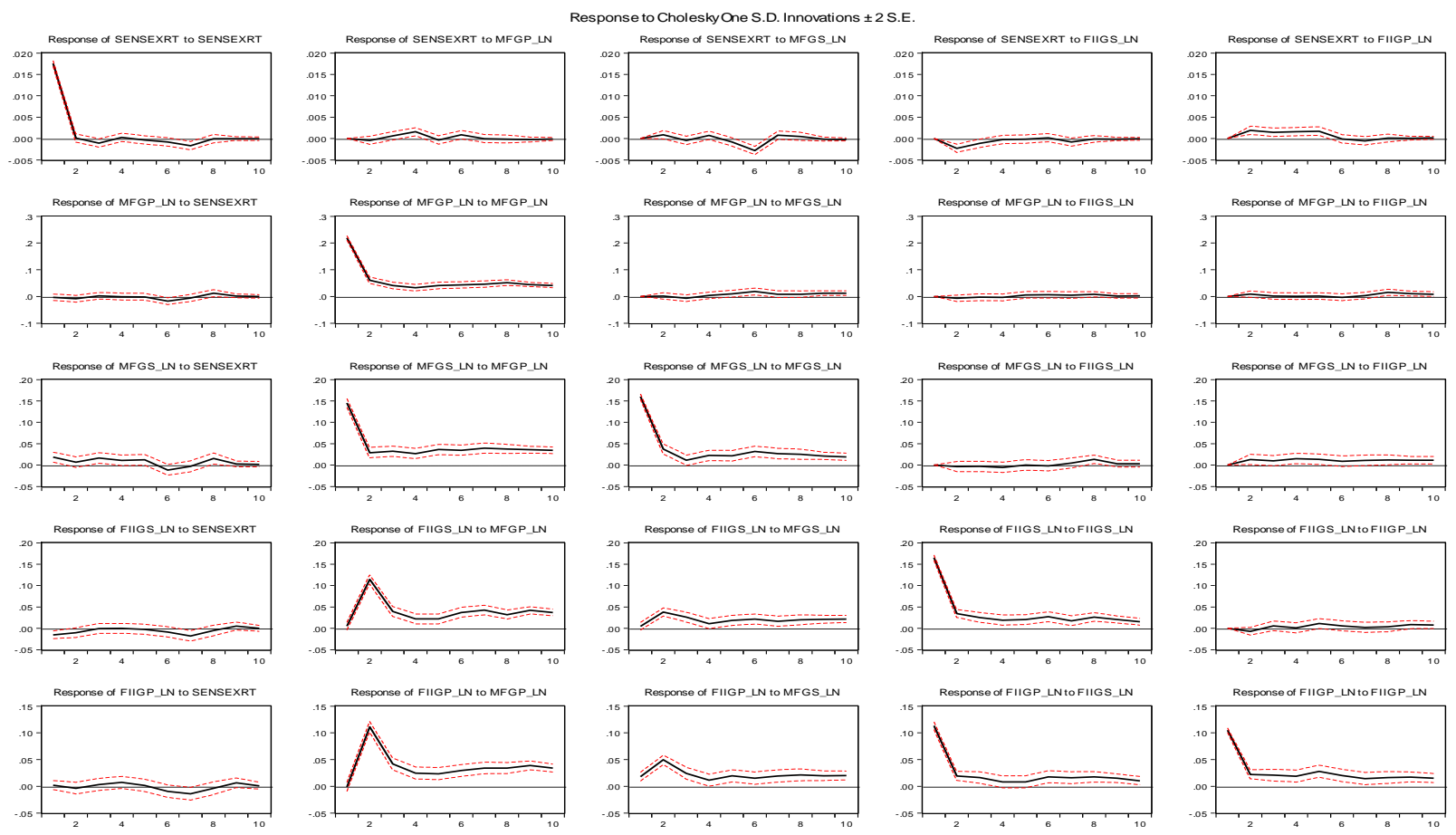

Figure -2

From 03-08-2009 to 31-12-2015
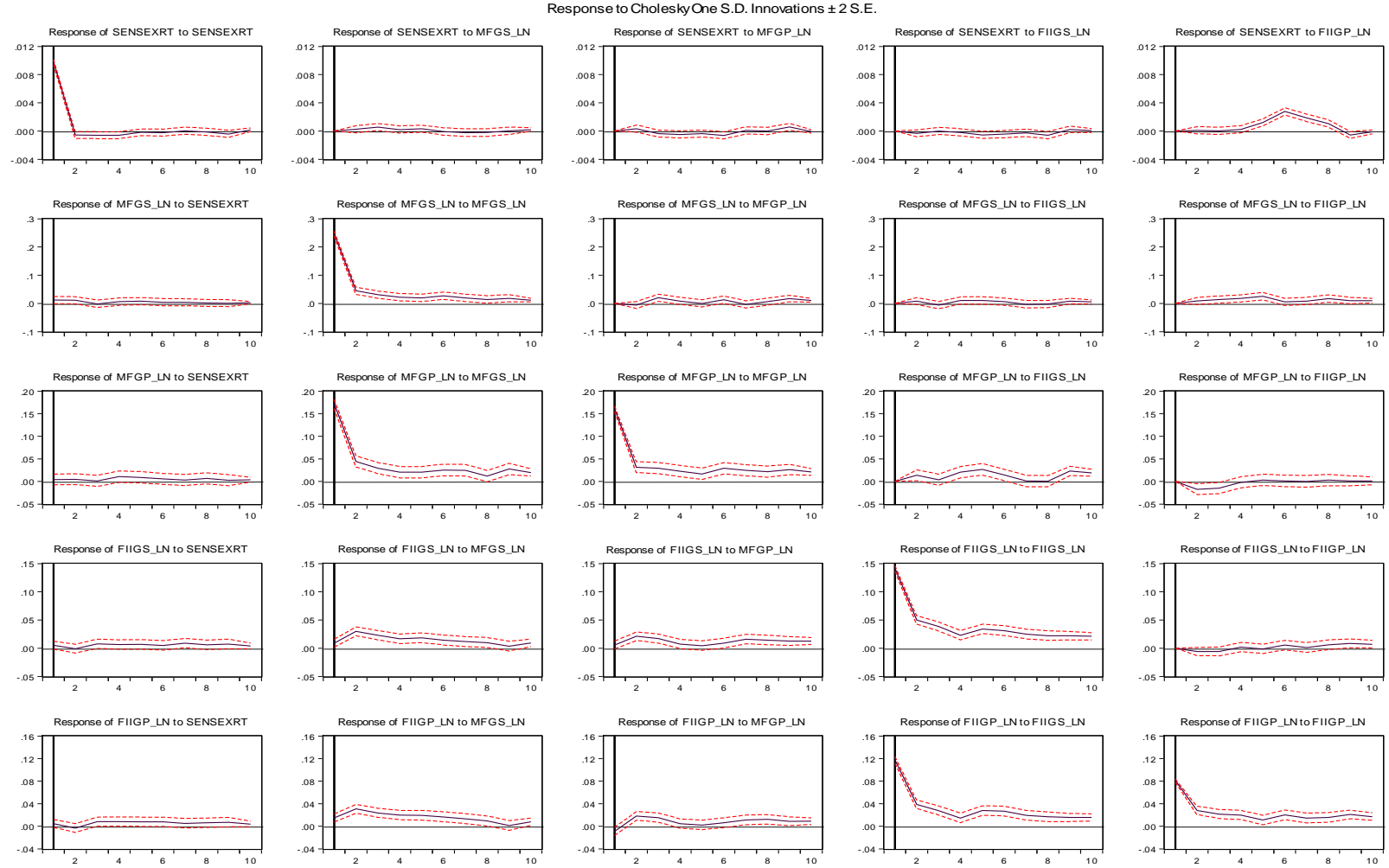


\section{Analysis}

The Impulse Response Function for the period between 02-01-2004 to 31-07-2009 shows that when there was a decrease in Sensex Returns, it did not evoke any favourable response from both the investors of MF and FII to either sell or purchase the securities. But, when there was a change in FII Purchases, Sensex Returns increased for quite a while, also correspondingly MF responded mildly by selling. Also, change in MF Purchases tended to change in purchases by foreign institutions thereby Sensex Returns did not react. It is to observe that any change in MF Sales had resulted in the purchase by foreign investors thereby creating volatility in Sensex Returns. However, when there is a change in FII Sales, it has led to negative Sensex returns and MF were inactive.

During 03-08-2009 to 31-12-2015, however, a decrease in Sensex Returns led to MF purchases. When FII indulged in Purchases, MF Sales did not respond even though the status of Sensex Returns remained the same. The market has recovered as Sensex returns reacted positively towards MF purchases and there was also a corresponding change in FII purchases. MF investors were not keen on participating in the market but FII showed interest in investing in Indian markets rather than selling their investments. However, immediate sales of FII is observed however not over along period.

\section{FINDINGS}

To make an empirical model effective, it is pertinent that stability of the variable is checked. In this study, it was found that there was a break in the data (as per Bia-Perron Test) due to an economic slowdown across the globe once during the period chosen for the study. Hence the variables were divided into two groups for the analysis.

Average Sales and Purchases of FII and MF got increased (during 2009-2015). But Sensex Returns decreased during this time. Mutual Fund and FII Purchases and Sales earlier had a positive relation amongst themselves but later the relation decreased however remained positive. MFGP and FIGS had a negative relation with Sensex Returns right from the beginning until the end of measurement in this study.

In the beginning, Sensex Returns was self-reliant (87\%) for its performance in the market during the period taken for the study and later its reliance on itself fell marginally (84\%). Mutual Fund Gross Sales were not much self-reliant before (47\%) but became almost self-reliant later (95\%). MF Gross Purchases were earlier very self-reliant (97\%) but later was caused by other variables (42\%). FII Gross Sales during the earlier period of study was considerably effected by MF Gross Purchases (38\%) but later managed to be self-reliant (85\%). FII Gross Purchases was initially effected by MF Gross Purchases (38\%) and later was majorly effected by FII Gross Sales (57\%).

In the earlier period under this study, to begin with, Sensex Returns appeared stable. But soon due to considerable selling activities of Foreign Institutional Investors, there was a perceived variation in Sensex Returns and soon declined notably. While such a decline continued, the scenario benefitted Mutual Fund and Foreign Institutional Investors to invest in the market.

\section{CONCLUSION}

On observing the behaviour of the market variables, Indian investors seem to be not proactive in playing in the market when Mutual Fund interacts with the market, but when FII interacts with the market, investors are keen on the behaviour of the market.

When there is a slow-down in the economy, the market returns and the activities of Mutual Fund or Foreign Institutional Investors will reduce and while in the recovery process of the economy, their purchasing activity shall increase.

It is observable from the study that Mutual Fund and FII share a fair amount of good relation among themselves. Any variation in this relation may cause volatility in the market. 
It is well known now that Indian stock market is driven by more of outsiders, i.e., Foreign Investors rather than domestic investors, i.e., Mutual Fund. It is high time, the government takes some initiatives to improve domestic investments so that market stability can be restored.

\section{References}

Bodla, B. S., \& Kumar, A. (2009). Foreign Institutional Investors and Macroeconomic Variables in India: A Study of Causal Relation. Paradigm (09718907), 13(2), 80-87.

Bulsara, H. P., Dhingra, V. S., \& Gandhi, S. (2015). Dynamic Interactions between Foreign Institutional Investment Flows and Stock Market Returns - The Case of India. Contemporary Economics, 9(3), 271-298. https://doi.org/10.5709/ce.1897-9254.170

Dandapani, K., \& Lawrence, E. R. (2013). Foreign Institutional Investment in India. Finance India, $27(2), 409-419$.

Garg, A., \& Mitra, S. (2015). A study of lead-lag relation between FIIs herding and stock market returns in emerging economies: evidence from India. Decision (0304-0941), 42(3), 279-292. https://doi.org/10.1007/s40622-015-0080-6

Kumar, S. (2009). Investigating causal relationship between stock return with respect to exchange rate and FII: evidence from India. MPRA Paper, MRPA Paper 15793 , 1-20. Retrieved from http://mpra.ub.uni-muenchen.de/15793/

Mohanasundaram, \& Karthikeyan. (2012). Impact of Institutional Investments and Macro-Economic Variables in the Indian Equity Market. International Research Journal of Finance and Economics(94), 70-78.

Mukherjee, P., Bose, S., \& Dipankor. (2002). Foreign Institutional Investment Iin Indian Equity Market An Analysis of Daily Flows during Jan 1999- May 2002. Money \& Finance ICRA Bullitien, April-Sept. 2002, 21-51.

Narender, J. (2013). Role of Domestic Investors in Foreign Equity Investment for Economic Growth of Country. International Journal of Science Technology \& Management, 1(1), 1-7.

Patnaik, I., \& Shah, A. (2013). The investment technology of foreign and domestic institutional investors in an emerging market. Journal of International Money and Finance, 39, 65-88. https://doi.org/10.1016/j.jimonfin.2013.06.019

Ray, K. K. (2009). Foreign Institutional Investment Flow \& Indian Stock Market Returns: A Relationship Study. Vilakshan: The XIMB Journal of Management, 6(1), 39-58.

Sehgal, S., \& Tripathi, N. (2009). Investment Strategies of FIIs in The Indian Equitymarket. The Journal of Business Perspective, 13(1), 11-18. doi:10.1177/097226290901300102

Sumanjeet, P. (2010). Liberalization of Foreign Institutional Investments (FIIs) In India: Magnitude, Impact Assessment, Policy Initiatives and Issues. Global Journal of International Business Research, 3(3), 22-41.

Thiripalraju, M., \& Acharya, R. (2013). Dynamic Interaction between Institutional Investment and Stock Returns in India: A Case of FIIs and MFs. Finance India, 27(4), 1173-1191.

Tripathi, V., \& Maggo, S. (2015). An Empirical Analysis of Foreign Institutional Investments in Equity \& Debt Market in India. Journal of International Economics (0976-0792), 6(1), 107117. 